\title{
The quality characteristics of dough and toast bread prepared with wheat flour containing different levels of Portulaca oleracea leaf powder
}

\author{
Natali SADEGHZADEH BENAM ${ }^{1}$, Mohammad GOLI ${ }^{1,2 *}$ (D), Seyed Mahdi SEYEDAIN ARDEBILI ${ }^{3}$, \\ Niloufar VAEZSHOUSHTARI ${ }^{1}$
}

\begin{abstract}
Rheological characteristics, i.e., farinograph and extensograph test in dough, specific-volume, hardness, sensory-properties, and the physicochemical-properties of toast-bread containing four levels (0-15\%) of Portulaca oleracea leaf-powder (PLP) based on flour weight were determined. The water absorption and development-time of the dough sample increased with the addition of PLP. The increase in the PLP content in the dough sample from $10 \%$ to $15 \%$ showed significant differences in dough-stability. The energy and extensibility of dough increased for 5 and $10 \%$ and then decreased for $15 \%$ PLP substitution levels at dough resting time 45, 90, and 135 minutes after production. The specific-volume decreased and the pressure force reversely increased stepwise by 5 up to $15 \%$ dosage. Sensory-evaluation indicated that $10 \%$ of PLP in the bread is the most acceptable-level, more enriched-bread variants were less acceptable mainly owing to having less significant colour and sensory indices $(\mathrm{p}<0.05)$, meanwhile dough water-absorption and specific-volume had no significant difference compared to less enriched bread samples $(\mathrm{p}>0.05)$. As expected, the colour changed, too, from light brown (the control) to dark green (for $15 \%$ the PLP in bread). The moisture, dietary-fiber, protein, ash, and fat content significantly increased in the toast-bread, reflecting the enhancement levels.

Keywords: Portulaca oleracea leaf powder; toast bread; dough rheology; bread physico-chemical properties; bread staling.

Practical Application: Water absorption and development time of dough containing PLP increased. Energy and extensibility of dough containing PLP decreased. The most acceptable level for sensory evaluation is $10 \%$ of PLP in bread. The colour assessment, specific volumes were different in PLP bread.
\end{abstract}

\section{Introduction}

Portulaca oleracea $(\mathrm{PO})$ is an annual herb of the Portulacaceae family, which may reach $40 \mathrm{~cm}$ (16 in) in height. PO leaves are stalkless, oval, smooth, succulent, and shiny, and vary from 0.5 to 2 inches in length with sour taste and without any smell. This plant is native to Iran and has a cultivation history of 2,000 years (Stephan, 1994). Portulaca oleracea protein, dietary fiber contents (to be compared to wheat flour) is also a source of carotenoids and non-vitamin and important antioxidants. It also contains remarkable amount of potassium, calcium, magnesium, iron, $\omega_{3}$ and $\omega_{6}$ fatty acids, and other essential fatty acids (Rubatzky \& Yamaguchi, 1997; De Lorgwril et al., 2001). The linolenic acid, which is the most common poly-unsaturated fatty acid and the precursor of other $\omega_{3}$ long-chain fatty acids, and eicosapentaenoic, docosapentaenoic, and docosahexaenoic acids are present in PO (Omara-Alwala et al., 1991). The positive effects of these $\omega_{3}$ fatty acids on cardiovascular diseases has led to the use of PO as a cheap and rich source of healthy fatty acids. Naghavi et al. (2011) have studied the effect of wheat flour enrichment along with $\mathrm{PO}$ grain powder on the rheological properties of bread dough. A decrease in water absorption, dough resistance, and the farinograph quality number were observed in the results of this experiment. Also, an increase in the PO powder content in wheat flour blend caused a high level of dough weakness, which, in turn, reduced the rheological properties of dough. Moreover, Fathnejhad-Kazemi et al. (2012) studied the effects of the addition of $\mathrm{PO}$ grain powder on the chemical characteristics, fatty acid profile, and sensory qualities of wheat bread. The results revealed that the addition of more than $10 \%$ of $\mathrm{PO}$ powder weakened the rheological characteristics of wheat dough. Furthermore, the addition of PO powder up to $20 \%$ led to an increase in the contents of oil, linolenic fatty acid, tocopherol, and the acidity of samples. The substitution by milled freeze-dried PO at four levels - 5, 10, 15, and 20\% - in the formula resulted in a special kind of bread with a higher level of essential fatty acids compared to other products, e.g. enhanced by soybean protein (Award et al., 2009). Therefore, this paper studies the effect of $\mathrm{PO}$ leaf powder on the rheological characteristics of dough through farinograph and extensograph tests further goal was evaluation of the physicochemical, textural, 
sensory, and hardness characteristics of fresh toast bread as well as during storage test.

\section{Materials and methods}

\subsection{Preparation of wheat flour and Portulaca oleracea leaf powder}

Winter white hard wheat (Triticum aestivum $\mathrm{L}$.) harvested in Isfahan province, Iran in June 2018 and milled with an industrial miller (Varamin Flour Milling Industrial Co., Iran). Its granulation corresponded to fine flour, at least $50 \%$ of the particles pass through a sieve of $125 \mu \mathrm{m}$. Common quality parameters of the flour including protein content $11.45 \%$ (the wet gluten content $28.2 \%$ ), the Zeleny sedimentation value about $30 \mathrm{~mL}$, and the Falling number $345 \mathrm{~s}$; further, fat, crude fiber, and ash contents were $1.74,0.82$, and $0.79 \%$, respectively. Also, leaves $(50 \mathrm{~kg}$ ) cut off from $\mathrm{PO}$ herb stems were dried manually with an electrical fan oven (dry bulb temp. of $65^{\circ} \mathrm{C}$, wet bulb temp. $40^{\circ} \mathrm{C}$ and relative humidity $22.5 \%$ ). Milling was carried out by using laboratory grinder (Model GM200, Retsch, Germany), and then turned into a powder about $3.95 \mathrm{~kg}$; at least $50 \%$ of the particles pass through a sieve $125 \mu \mathrm{m}$. Common quality parameters of PLP including the moisture, fat, protein, crude fiber, and ash contents were $11.5,16.1,26.2,15.1,13.84 \%$, respectively.

\subsection{Dough and bread production}

White flour and PO leaf power (PLP) at a specific proportion $(0,5,10$, or $15 \%), 2.0 \%$ dry yeast, $2.0 \%$ salt, and $1.5 \%$ flour improver based on ascorbic acid and L-cysteine (50:50; Merck, Germany) were mixed together into dry premix (percentage based on flour weight). Owing to bread preparation on industrial mixer, following the El-Demery method (El-Demery, 2011) with partial modifications, correct water addition of this premix was determined on farinograph (Brabender, Germany) to reach the prescribed dough consistency 500 Brabender units (BU; column 'Water absorption' in Table 1). Salt, flour, and the flour improver were mixed in an industrial mixer (5L Planetary cake mixer, Foodsense, China), equipped by bowl for 25 litres. A portion of tap water was used to make yeast suspension, which was incubated for 20 minutes at $35{ }^{\circ} \mathrm{C}$. Subsequently, the powder was added to the premix along with the remaining water. The materials were mixed by hooks beater for 10 minutes at 60 RPM. The dough, then, was fermented in an industrial fermentation cabinet (Aocno-bakery Co., China) at $28 \pm 1{ }^{\circ} \mathrm{C}$ for 90 minutes and divided instrumentally into small $250 \mathrm{~g}$ portions (12 portions for dough analysis and 48 portions for toast bread analysis) by rolling technique; it was again fermented at $35-37^{\circ} \mathrm{C}$ for
90 minutes with the relative humidity set to $70-75 \%$. After the baking into an industrial oven without initial steaming (fullautomatic tunnel oven, Mashhad baking industries Co., Iran) at $250{ }^{\circ} \mathrm{C}$ for 30 minutes, the baked bread was removed from the pan and allowed to cool off at room temperature $25^{\circ} \mathrm{C}$ for $1 \mathrm{~h}$. Next, it was packed and kept in Ziploc vacuum bags (low-density polyethylene) until further analysis at room temperature $20^{\circ} \mathrm{C}$ and relative humidity $50 \%$ for 24,48 , and $72 \mathrm{~h}$ depending on the type of tests (Ewerling et al., 2020; Guijarro-Fuertes et al., 2019; Kouassi-Koffi et al., 2019).

\subsection{Laboratory analysis}

Rheological properties of the leavened "two-composite" dough of the toast bread were described by both the farinograph test (farinograph, model E, Brabender, Germany) and the extensograph one (extensograph, model E, Brabender, Germany) performed according to the methods AACC 21-54 and AACC 54-10, respectively (American Association of Cereal Chemistry, 2008; Kouassi-Koffi et al., 2019). In the toast bread, the moisture content was determined by using of the laboratory oven set to $105^{\circ} \mathrm{C}$, relative humidity $1.1 \%$ (INB 400 , Memmert, Germany) according to the AACC method No. 14-15. Evaluation of the ash content was carried out by using laboratory stove model 1252 (Memmert, Germany), following the AACC method No. 08-01. Evaluation of the total protein content was carried out by using Kjeldahl analyser model 8400 (Kjeltec, Switzerland), following the AACC No. 12-46. Evaluation of the total fat content was carried out by using Soxhelt extractor model PBI (Buchi, Italy), following the AACC No. 30-25 (Karshenas et al., 2019). Evaluation of the $\mathrm{pH}$ was carried out by using $\mathrm{pH}$ meter model MP220 (Mettler Toledo, Switzerland), following the AACC No. 02-52.01. The dietary fiber was evaluated based on the enzymatic-gravimetric method by using of apparatus EN 6, dietary fiber digestion (Velp-Petratech, Germany), following the AOAC procedure No. 991.43 (Association of Official Analytical Chemists, 1995). The specific volume of the bread was determined by using the flaxseed volume displacement, following the AACC No. 10-05. The colour characteristics of the toast bread were measured on spectrophotometer YS3060 (Colour Hunter Lab, USA) (Mirani \& Goli, 2021b; Ewerling et al., 2020; Parsaei et al., 2018; Karshenas et al., 2018; Farokhian et al., 2017). The bread staling was expressed as crumb compressibility (hardness), performed at time intervals of 24,48 and $72 \mathrm{~h}$ after baking by using the Instron machine (Santam-STM5 Instron, Iran) with a probe diameter of $21-25 \mathrm{~mm}$ and load-cell $50 \mathrm{~N}$, following the AACC No. 09-74 (Mirani \& Goli, 2021a; Zonoubi \& Goli, 2021; Sazesh \& Goli, 2020; Guijarro-Fuertes et al., 2019). In doing so samples were stored at plastic bags at ambient temperature

Table 1. The effect Portulaca oleracea Leaf Powder (PLP) on farinograph characteristics of wheat flour.

\begin{tabular}{|c|c|c|c|c|c|c|}
\hline $\begin{array}{c}\text { PLP substitution } \\
(\%)\end{array}$ & $\begin{array}{c}\text { Water absorption } \\
(\%)\end{array}$ & $\begin{array}{c}\text { Dough development } \\
\text { time }(\mathrm{min})\end{array}$ & $\begin{array}{c}\text { Dough stability } \\
\text { time (min) }\end{array}$ & $\begin{array}{l}\text { Degree of softening } \\
\text { after } 10 \mathrm{~min}(\mathrm{BU})\end{array}$ & $\begin{array}{c}\text { Degree of softening } \\
\text { after } 12 \mathrm{~min}(\mathrm{BU})\end{array}$ & $\begin{array}{c}\text { Farinograph quality } \\
\text { number }(\mathrm{mm})\end{array}$ \\
\hline 0 & $59.9 \pm 1.2^{\mathrm{b}}$ & $2.5 \pm 0.5^{c}$ & $7.2 \pm 0.2^{\mathrm{a}}$ & $50.0 \pm 0.0^{c}$ & $68.5 \pm 1.5^{\mathrm{d}}$ & $73.0 \pm 2.0^{b}$ \\
\hline 5 & $60.2 \pm 0.2^{\mathrm{b}}$ & $5.1 \pm 0.1^{\mathrm{b}}$ & $5.4 \pm 0.0^{\mathrm{b}}$ & $93.5 \pm 4.5^{\mathrm{a}}$ & $146.0 \pm 5.0^{\mathrm{a}}$ & $67.5 \pm 1.5^{\mathrm{c}}$ \\
\hline 10 & $61.5 \pm 15.0^{\mathrm{a}}$ & $5.5 \pm 0.3^{b}$ & $5.7 \pm 0.2^{b}$ & $91.5 \pm 2.5^{\mathrm{a}}$ & $131.0 \pm 3.0^{\mathrm{b}}$ & $69.5 \pm 2.5^{b c}$ \\
\hline 15 & $62.3 \pm 0.0^{\mathrm{a}}$ & $6.6 \pm 0.2^{\mathrm{a}}$ & $6.9 \pm 0.3^{\mathrm{a}}$ & $62.0 \pm 7.0^{\mathrm{b}}$ & $112.5 \pm 3.5^{c}$ & $81.0 \pm 3.0^{\mathrm{a}}$ \\
\hline
\end{tabular}

$\mathrm{BU}=$ Brabender unit; Different letter in each column indicates a significant difference $(\mathrm{p}<0.05)$. 
followed by cutting bread slices $10 \mathrm{~mm}$ thick with dimensions of $20 \times 20 \mathrm{~mm}$ for measurement of hardness by Instron machine. Compression exerted equals to $40 \%$ of samples' diameter (American Association of Cereal Chemistry, 2008). The sensory characteristics of the bread were also determined one day after bread preparation, employing 10-trained panellists; five-point hedonic scale was prescribed, when the higher score means the higher quality (Sass et al., 2020; Costa et al., 2020; Guimarães et al., 2019; Nazari \& Goli, 2017).

\subsection{Experimental design and statistical analysis}

All tests were conducted in a completely randomized design in independent triplicates to confirm the reproducibility of the results (Maghamian et al., 2021; Jalalizand \& Goli, 2021). The report of the data was given as mean $\pm \mathrm{SD}$. The one-way ANOVA was performed to assess the farinograph, chemical characteristics, and specific volume data. The two-way ANOVA was performed to assess moisture content in bread, and further the extensograph, and hardness data. Duncan's multiple range test determined significant differences, at the $95 \%$ confidential level ( $\mathrm{p}<0.05$ ) using statistical SPSS software version 16 (Chicago, SPSS Inc., USA) (Zaghian \& Goli, 2020).

\section{Results and discussion}

\subsection{Dough rheological characteristic}

\subsubsection{Farinograph test}

\subsubsection{Water absorption}

The farinograph characteristics of the dough made from white flour and PLP blends are shown in Table 1. Based on the results, the addition of different PLP levels in the flour caused a soft increase in water absorption in samples. This led to a significant prolongation of the dough development time from $2.5 \mathrm{~min}$ for the control to $6.6 \mathrm{~min}$ in the $15 \%$ PLP sample.

\subsubsection{Dough development time}

The concomitant diluting effect of non-gluten proteins cause an increase in either water absorption or dough development time and a decrease in dough stability time at all the replacement levels of flour by PLP, similarly to effect of Chia whole flour substituted with wheat flour in 5\% level in dough and bread (Iglesias-Puig \& Haros, 2013). Time of dough stability refers to the resistance to the mixing exhibited by the dough - a maximal shortening reached $25 \%$ (Table 1 ).

\subsubsection{Dough softening (MTI)}

Up to $10 \%$ level, the addition of PLP into wheat flour led to declining in dough stability time in comparison with the control. To the same results arrived Naghavi et al. (2011); similar effect was proven for chia- or quinoa-seed flour substituting wheat flour in cookie dough (Goyat et al., 2018). A raise in dough stability time refers to the stability of the dough structure during a mechanical stress (an unsteady deformation). According to the results, the $15 \%$ PLP dough sample had stability similar to the control, while the 5 and $10 \%$ PLP samples had shorter dough stability than the control. The addition of different levels of PLP in the wheat flour led to an increase in the degree of softening after 12 minutes (known also as the mixing tolerance index, MTI) compared to the control. However, the higher enhancement by PLP, the lower degree of dough weakness after 12 min of kneading. As expected, the control had the lowest degree of softening and a longer dough stability time during mixing (i.e. the "strongest" proteins). As the percentage of PLP increased, the degree of softening decreased, implying that dough strength depends on its stability indirectly (Naghavi et al., 2011).

\subsubsection{Farinograph quality number}

The farinograph quality number (FQN) describes the flour quality in the compressed form, i.e., by one value only - weak flour has a low FQN, while stronger flour samples show higher FQN. Instead of calculating multiple indicators in farinograph tests, this single number can be used to report the quality of flour or flour blend, specifying the final usage purpose for production of different types of cereal products. Simplified, the FQN could be interpreted as the prolonged dough stability. However, for practical application, the mentioned feature it did not find its place yet. Nonetheless, Fu et al. (2008) proved tight correlation between this parameter and the other farinograph characteristics. As mentioned supra, there is a direct linkage between the FQN and flour sample quality. A sample containing 15\% PLP has the highest quality number. The FQN increased reversely to PLP additions, the reason is a decrease in dough stability as well as a rise in the degree of softening of dough prepared with PLP. Overall, 5\% addition of PLP caused relatively the highest changes in farinograph behaviour of wheat flour control, perhaps owing to the strongest disruption of the gluten skeleton. A higher PLP dosages had not so serious effect, likely due to introduction of higher portion dietary fiber, supplementing a role of gluten.

\subsubsection{Extensograph test}

Table 2 exhibited the extensograph characteristics in the dough made from white flour and PLP; there was a comparison of records data after three times of dough resting presented. Dough resistance to tension (elasticity) magnified as the ratio of the added PLP increased. The lowest and highest elasticity for three time-points $(45,90$, and $135 \mathrm{~min})$ were related to the control (0\%) and the 15\% PLP sample, respectively. The increase in the PLP percentage in wheat flour significantly decreased dough elasticity, which exhibits the dough viscose habit and is related to the presence of gliadins, too. This showed the negative effect of PLP ingredient on dough elasticity and in addition, it is also related to the insoluble fiber component of PLP, leading to early gluten ruptures during one-dimensional extension. Another reason may be the dilution of gliadin proteins that altered the gliadin-to-glutenin ratio. The elastic properties associated with the presence of glutenin were strengthened, while the viscous properties of the dough were due to the effect of gliadin being weakened. The ratio number increased with increases in the percentage of PLP and dough resting time $(45,90$, or $135 \mathrm{~min})$. Dough energy as the area under the curve called extensogram represented the energy needed to stretch the dough to tear it or mechanical work portion in 
Table 2. The effect Portulaca oleracea Leaf Powder (PLP) on extensograph characteristics of wheat flour.

\begin{tabular}{|c|c|c|c|c|c|}
\hline Dough resting time $(\mathrm{min})$ & PLP substitution (\%) & Resistance to tension* $(\mathrm{BU})$ & Extensibility $(\mathrm{mm})$ & Ratio number (-) & Energy $\left(\mathrm{cm}^{2}\right)$ \\
\hline \multirow{4}{*}{45} & 0 & $295.5 \pm 0.5^{\mathrm{d}}$ & $189.7 \pm 7.6^{\mathrm{a}}$ & $1.37 \pm 0.60^{\mathrm{d}}$ & $92.7 \pm 2.9^{\mathrm{b}}$ \\
\hline & 5 & $462.5 \pm 12.5^{c}$ & $152.6 \pm 1.1^{\mathrm{b}}$ & $3.04 \pm 0.11^{\mathrm{c}}$ & $118.7 \pm 3.4 \mathrm{a}$ \\
\hline & 10 & $739.5 \pm 22.5^{\mathrm{b}}$ & $116.5 \pm 0.4^{c}$ & $6.35 \pm 0.21^{\mathrm{b}}$ & $119.1 \pm 6.4 \mathrm{a}$ \\
\hline & 15 & $942.5 \pm 28.5^{\mathrm{a}}$ & $81.5 \pm 2.5^{\mathrm{b}}$ & $11.55 \pm 0.05^{\mathrm{a}}$ & $97.5 \pm 4.5^{\mathrm{b}}$ \\
\hline \multirow{4}{*}{90} & 0 & $305.0 \pm 8.0^{\mathrm{d}}$ & $181.0 \pm 5.2^{\mathrm{a}}$ & $1.69 \pm 0.01^{\mathrm{d}}$ & $100.7 \pm 4.3^{c}$ \\
\hline & 5 & $664.0 \pm 11.0^{c}$ & $160.6 \pm 3.5^{\mathrm{b}}$ & $4.14 \pm 0.02^{\mathrm{c}}$ & $174.3 \pm 3.9^{\mathrm{a}}$ \\
\hline & 10 & $896.0 \pm 32.0^{\mathrm{b}}$ & $111.0 \pm 3.2^{\mathrm{c}}$ & $8.07 \pm 0.06^{\mathrm{b}}$ & $136.1 \pm 9.1^{\mathrm{b}}$ \\
\hline & 15 & $993.0 \pm 1.0^{\mathrm{a}}$ & $96.0 \pm 3.0^{\mathrm{d}}$ & $10.35 \pm 0.35^{\mathrm{a}}$ & $130.0 \pm 10.0$ \\
\hline \multirow{4}{*}{135} & 0 & $297.0 \pm 7.0^{c}$ & $177.9 \pm 6.3^{\mathrm{a}}$ & $1.67 \pm 0.02^{\mathrm{d}}$ & $95.2 \pm 5.4^{\mathrm{d}}$ \\
\hline & 5 & $709.0 \pm 19.0^{\mathrm{b}}$ & $147.4 \pm 5.6^{\mathrm{b}}$ & $4.82 \pm 0.31^{c}$ & $168.8 \pm 5.6^{\mathrm{a}}$ \\
\hline & 10 & $991.0 \pm 1.0^{\mathrm{a}}$ & $108.9 \pm 0.3^{c}$ & $9.14 \pm 0.05^{\mathrm{b}}$ & $151.1 \pm 1.0^{\mathrm{b}}$ \\
\hline & 15 & $990.5 \pm 2.5^{\mathrm{a}}$ & $83.0 \pm 3.0^{\mathrm{d}}$ & $11.9 \pm 0.40^{\mathrm{a}}$ & $115.5 \pm 4.5 \mathrm{c}$ \\
\hline
\end{tabular}

${ }^{\star}$ relation to dough elasticity, i.e. tenacity; $\mathrm{BU}=$ Brabender unit. Different letter in each column for each dough resting time indicates a significant difference $(\mathrm{p}<0.05)$.

the dough; it is a good indicator of the bakery technological potential (in bakers' slang, flour strength; Balestra, 2009). The increasing energy consumption could be attributed to increases in dough extensibility. Dough tension improvement led to the improvement of water- and gas-holding capacity of dough, which had a remarkable effect in the reduction of hardness and increases in the freshness of the bread. The above-mentioned finding is in accordance with the results of Naghavi et al. (2011), who studied the substitution of wheat flour by PLP, too. The extensograph tests for different doughs containing amaranth were not greatly affected by adding amaranth meal. Concluded, the amaranth meal seemed to have an improvement nature like strong wheat flour (Sharoba et al., 2009).

\subsection{Bread characteristics}

\subsubsection{Evaluation of specific volume of bread}

Table 3 shows the specific volumes of bread variants prepared from white wheat flour-PLP blends. In comparison with the control, the addition of PLP at different levels led to a reduction in the specific volumes of the produced bread, especially in case of 15\% PLP enhancement ( $p<0.05)$. This insignificant diminishing is due to the substitution of wheat proteins with the PLP ones, i.e. the weakening of the gluten network. Diluted gluten skeleton consecutively had a lessened capacity to capture fermentation gases; in praxis, standard time of dough leavening should be shortened and dough pieces inserted into preheated oven in time of maximal volume.

\subsubsection{Hardness evaluation}

The results of the Instron experiment, compared to the bread samples made from white flour and PLP showed in Table 3 and in Figure 1. After 24, 48 and 72 hours of production time, among the bread samples containing PLP, the bread sample containing 5\% PLP demonstrated the highest hardness. For the bread containing 15\% PLP reversely, the hardness occurred in the lowest extent; there was no significant difference compared to the control ( $p>0.05)$, i.e. the addition of PLP in bread recipe led to a decrease in hardness. The bread sample containing $15 \%$ PLP was the softest because hardness has been decelerated, due

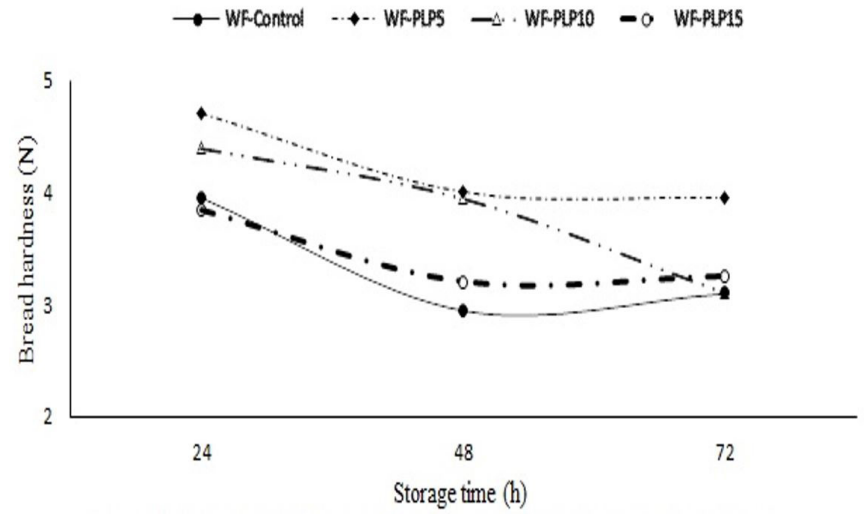

Figure 1. The hardness of toast bread prepared with flour containing different levels of Purtulaca oleracea leaf powder in the different storage times.

to weakness in the gluten network as well as due to trapped water. There was a negative correlation between the hardness and the percentage of PLP added to the toast bread $(r=0.95$; $\mathrm{p}<0.05$ ). In other words, introduction of dietary fibre by PLP elevated the water holding capacity of flour blend, the moisture content in dough as well as in baked bread, and consequently crumb softness (less hardness) of the finished product. This is in agreement with the results of the tests of Fathnejhad-Kazemi et al. (2012) involving the PO seed and linseed powder used in the bread formula.

\subsubsection{Colour assessment in toast bread}

According to Table 4, all three colour indexes of the CIE Lab space reflected a proportional change in bread recipe. Due to that, colour coordinate lightness $L^{*}$ significantly fell for the bread samples containing PLP compared to wheat bread control. Summarised, expected darkening of bread crust and crumb occurred because of the PLP addition even at the 5\% substitution level. A higher relative change could be calculated for the redness/yellowness. In sum, total colour change delta E had proportionally risen from 31 to 42 , indicating significantly different e.g. between bread variants with 5\% and 15\% PLP. Comparable effect was reported up to 5-6\% substitution whole black chia 
Table 3. The effect Portulaca oleracea Leaf Powder (PLP) on specific volume and hardness of the toast bread.

\begin{tabular}{|c|c|c|c|c|}
\hline \multirow{2}{*}{ PLP substitution (\%) } & \multirow{2}{*}{$\frac{\text { Specific volume }\left(\mathrm{cm}^{3} / \mathrm{g}\right)}{24 \mathrm{~h} \text { after bread preparation }}$} & \multicolumn{3}{|c|}{ Hardness (N) Time after bread preparation (h) } \\
\hline & & 24 & 48 & 72 \\
\hline 0 & $5.38 \pm 0.15^{\mathrm{a}}$ & $3.95 \pm 072^{\mathrm{bc}}$ & $2.95 \pm 0.50^{\mathrm{b}}$ & $3.10 \pm 0.77^{\mathrm{b}}$ \\
\hline 5 & $5.32 \pm 0.14^{\mathrm{ab}}$ & $4.70 \pm 0.35^{\mathrm{a}}$ & $4.00 \pm 058^{\mathrm{a}}$ & $3.95 \pm 0.60^{\mathrm{a}}$ \\
\hline 10 & $5.32 \pm 0.15^{\mathrm{ab}}$ & $4.40 \pm 0.52^{\mathrm{ab}}$ & $3.95 \pm 0.37^{\mathrm{a}}$ & $3.10 \pm 0.57^{b}$ \\
\hline 15 & $5.11 \pm 0.04^{\mathrm{b}}$ & $3.85 \pm 0.47^{\mathrm{c}}$ & $3.20 \pm 0.54^{\mathrm{b}}$ & $3.25 \pm 0.59^{b}$ \\
\hline
\end{tabular}

Different letter in each column indicates a significant difference $(\mathrm{p}<0.05)$.

Table 4. The sensory evaluation and colour index of the toasted wheat bread as affected Portulaca oleracea Leaf Powder (PLP).

\begin{tabular}{|c|c|c|c|c|c|c|c|c|c|}
\hline \multirow{3}{*}{$\begin{array}{c}\text { PLP } \\
\text { substitution } \\
(\%)\end{array}$} & \multicolumn{4}{|c|}{ Sensory attributes (points) } & \multirow{3}{*}{ Total score } & \multicolumn{4}{|c|}{ Colour index } \\
\hline & \multicolumn{4}{|c|}{$24 \mathrm{~h}$ after bread preparation } & & \multicolumn{4}{|c|}{$24 \mathrm{~h}$ after bread preparation } \\
\hline & Flavour & Chewiness & Taste & $\begin{array}{l}\text { Crumb } \\
\text { colour }\end{array}$ & & $\begin{array}{c}\text { Yellowness } \\
\text { b* }^{*}\end{array}$ & Redness a* & Lightness L* & Delta E \\
\hline 0 & $4.05 \pm 0.50^{\mathrm{a}}$ & $3.90 \pm 0.46^{\mathrm{b}}$ & $3.95 \pm 0.39^{\mathrm{a}}$ & $4.00 \pm 0.58^{\mathrm{a}}$ & $15.9 \pm 0.48^{\mathrm{a}}$ & $1.98 \pm 0.00^{\mathrm{d}}$ & $21.54 \pm 0.02^{b}$ & $72.40 \pm 0.02^{\mathrm{a}}$ & - \\
\hline 5 & $3.00 \pm 0.41^{\mathrm{b}}$ & $4.00 \pm 0.53^{\mathrm{b}}$ & $3.00 \pm 0.41^{\mathrm{b}}$ & $2.90 \pm 0.40^{\mathrm{b}}$ & $12.9 \pm 0.44^{\mathrm{b}}$ & $2.34 \pm 0.01^{c}$ & $21.94 \pm 0.03^{\mathrm{a}}$ & $41.46 \pm 0.04^{\mathrm{b}}$ & $30.94 \pm 0.01^{\mathrm{c}}$ \\
\hline 10 & $4.00 \pm 0.41^{\mathrm{a}}$ & $4.75 \pm 0.26^{\mathrm{a}}$ & $4.00 \pm 0.41^{\mathrm{a}}$ & $3.95 \pm 0.39^{\mathrm{a}}$ & $16.7 \pm 0.37^{\mathrm{a}}$ & $2.83 \pm 0.07^{\mathrm{a}}$ & $19.58 \pm 0.17^{c}$ & $34.52 \pm 0.03^{c}$ & $37.94 \pm 0.08^{\mathrm{b}}$ \\
\hline 15 & $2.00 \pm 0.41^{\mathrm{c}}$ & $4.00 \pm 0.41^{\mathrm{b}}$ & $1.90 \pm 0.52^{\mathrm{c}}$ & $1.05 \pm 0.37^{\mathrm{c}}$ & $8.95 \pm 0.43^{c}$ & $2.68 \pm 0.00^{\mathrm{b}}$ & $18.82 \pm 0.10^{\mathrm{d}}$ & $30.69 \pm 0.02^{\mathrm{d}}$ & $41.80 \pm 0.09^{\mathrm{a}}$ \\
\hline
\end{tabular}

Delta $\mathrm{E}$ - total colour change, related to control wheat bread. Different letter in each column indicates a significant difference $(\mathrm{p}<0.05)$. Total assessment (Sensory and colour index) were done in the day after bread preparation. Sensory attributes: 5 points means the best, while 0 point unacceptable score.

Table 5. The chemical characteristics of the raw materials [a)] and toast wheat bread [b)] as affected by Portulaca oleracea Leaf Powder (PLP).

\begin{tabular}{|c|c|c|c|c|c|}
\hline \multicolumn{6}{|c|}{ a) Chemical composition of raw materials } \\
\hline Raw material & Ash (\%) & Protein $(\%)$ & Fat (\%) & Dietary fiber (\%) & $\mathrm{pH}$ \\
\hline Wheat flour & $0.79 \pm 0.01^{\mathrm{b}}$ & $11.45 \pm 0.03^{\mathrm{b}}$ & $1.74 \pm 0.04^{\mathrm{b}}$ & $0.82 \pm 0.05^{\mathrm{b}}$ & $6.51 \pm 0.02^{\mathrm{a}}$ \\
\hline PLP & $13.84 \pm 0.02^{\mathrm{a}}$ & $26.20 \pm 0.05^{\mathrm{a}}$ & $16.10 \pm 0.02^{\mathrm{a}}$ & $15.10 \pm 0.04^{\mathrm{a}}$ & $5.85 \pm 0.03^{\mathrm{b}}$ \\
\hline \multicolumn{6}{|c|}{ b) Chemical composition of wheat-PLP breads } \\
\hline \multicolumn{6}{|c|}{ PLP substitution (\%) } \\
\hline 0 & $2.32 \pm 0.08^{\mathrm{d}}$ & $12.25 \pm 0.13^{\mathrm{d}}$ & $2.08 \pm 0.08^{\mathrm{d}}$ & $0.87 \pm 0.03^{\mathrm{d}}$ & $5.38 \pm 0.15^{\mathrm{a}}$ \\
\hline 5 & $3.70 \pm 0.11^{\mathrm{c}}$ & $13.6 \pm 0.18^{c}$ & $2.73 \pm 0.07^{c}$ & $1.96 \pm 0.05^{\mathrm{c}}$ & $5.32 \pm 0.15^{\mathrm{ab}}$ \\
\hline 10 & $5.45 \pm 0.22^{\mathrm{b}}$ & $14.63 \pm 0.13^{\mathrm{b}}$ & $3.12 \pm 0.10^{\mathrm{b}}$ & $2.44 \pm 0.06^{\mathrm{b}}$ & $5.32 \pm 0.14^{\mathrm{ab}}$ \\
\hline 15 & $6.01 \pm 0.03^{\mathrm{a}}$ & $15.76 \pm 0.13^{\mathrm{a}}$ & $3.93 \pm 0.08^{\mathrm{a}}$ & $2.89 \pm 0.14^{\mathrm{a}}$ & $5.11 \pm 0.04^{\mathrm{b}}$ \\
\hline
\end{tabular}

Different letter in each column indicates a significant difference $(\mathrm{p}<0.05)$. The total assessment was done one day after bread preparation.

meals with white flour in wheat bread (Romankiewicz et al., 2017; Iglesias-Puig \& Haros, 2013), also up 10\% substitution black or red quinoa with white flour in cookies (Goyat et al., 2018), caused the crumb colour considerably darkened.

\subsubsection{Sensory evaluation of toast bread}

Toast bread containing 10\% PLP had the highest sensory score after 24 hours of storage in terms of flavour, chewiness, taste, crumb colour, and total score (Table 4). Chewiness scores were in agreement with Instron results, i.e. the hardness, and farinograph parameters, e.g. the water absorption, showed that the bread sample containing 10\% PLP preserved its softness and freshness more than other samples. An increase in the PLP ratio from $5 \%$ to $10 \%$ and $10 \%$ to $15 \%$ increased and decreased the hardness sensory score (chewiness index). As the concentration of PLP increased, the $\mathrm{pH}$ decreased and the acidity due to PL sour taste, significantly increased (Lee et al., 2015; Stephan, 1994). The worst flavour score was for the PLP 15\%, perhaps due to the high content of PLP phenolic compound, i.e., $179.99 \mathrm{mg}$ gallic acid equivalent in $100 \mathrm{~g}$ PLP compared to $5.39 \mathrm{mg}$ gallic acid equivalent in $100 \mathrm{~g}$ wheat (Hussien \& Salem, 2016).

\subsubsection{Chemical characteristics of bread}

As can be seen in Table 5, since the mineral, protein, fat, and the dietary fiber content in the PLP is much higher in comparison with wheat flour (Stephan, 1994; De Lorgwril et al., 2001; Rubatzky \& Yamaguchi, 1997). Compared to the control, the increasing level of PLP caused a higher level of the listed nutrients, and lower $\mathrm{pH}$ in toast bread, thereby increasing the nutritional value of the toast bread prepared with PLP. In each three storage time-points (24, 48, and 72 hours after baking), there is a rise in the moisture level in agreement with used the PLP content (Table 6). The higher moisture content in the toast bread containing PLP compared with toasted wheat bread (the control) was due to the increased interaction ability of the greater amount of water with hydroxyl groups in the PLP fiber structure. This finding is in contrast to the results of Fathnejhad-Kazemi et al. (2012) while studying the PL seed and linseed powder on bread, using similar method of testing. Menteş et al. (2008) published 
Table 6. The effect Portulaca oleracea Leaf Powder (PLP) on bread moisture content during three days storage.

\begin{tabular}{cccc}
\hline \multirow{2}{*}{$\begin{array}{c}\text { PLP } \\
\text { substitution (\%) }\end{array}$} & \multicolumn{3}{c}{ Moisture content (\%) } \\
\cline { 2 - 4 } & \multicolumn{3}{c}{ Time after bread preparation $(\mathrm{h})$} \\
\hline 0 & $24.67 \pm 0.76^{\mathrm{d}}$ & $29.51 \pm 0.16^{\mathrm{d}}$ & $26.00 \pm 0.22^{\mathrm{c}}$ \\
5 & $32.94 \pm 0.25^{\mathrm{c}}$ & $33.07 \pm 0.18^{\mathrm{c}}$ & $32.02 \pm 0.49^{\mathrm{b}}$ \\
10 & $33.94 \pm 0.35^{\mathrm{b}}$ & $33.79 \pm 0.23^{\mathrm{b}}$ & $31.5 \pm 0.36^{\mathrm{b}}$ \\
15 & $36.9 \pm 0.44^{\mathrm{a}}$ & $35.01 \pm 0.15^{\mathrm{a}}$ & $33.01 \pm 0.30^{\mathrm{a}}$ \\
\hline Different letter in each column indicates a significant difference $(\mathrm{p}<0.05)$
\end{tabular}

also different findings, studying ground flaxseed influence on the quality and chemical composition of wheat bread. In listed cases, linseed powder and ground flaxseed decreased farinograph water absorption as well as portion of recipe water addition about 3.7 and 2.0 percent points at $15 \%$ substitution level, respectively.

\section{Conclusions}

Rheological characteristics, such as farinograph and extensograph dough features, specific volume, hardness, sensory properties, and the physicochemical properties of toast bread was determined. As was expected, farinograph testing confirmed that the dough's degree of softening decreased with increasing levels of Portulaca oleracea leaf powder (PLP). Moreover, the addition of PLP led to a significant prolongation in the dough development time. Extensograph specifications, such as dough resistance to tension (elasticity) increased, but extensibility and energy decreased in all the samples with the addition of PLP. The toast wheat bread was prepared with 5,10 , or $15 \%$ PLP. In bakery praxis, such change in dough rheological properties should represent a technical complication on automated production lines. From this viewpoint, the dough containing 10\% PLP had the highest potential in terms of specific bread volumes and crumb hardness. Further testing of consumer's quality by complex sensory profile revealed out the highest acceptability for wheat bread with $10 \%$ addition of PLP.

\section{Acknowledgements}

The authors would like to acknowledge the Islamic Azad University (IAU), Isfahan (Khorasgan) Branch, and Negin-Asal company (Isfahan, Iran, Ltd) for their scientific and valuable help and cooperation with this project.

\section{References}

American Association of Cereal Chemistry - AACC. (2008). Approved methods of American Association of Cereal Chemistry (10th ed.). St Paul: AACC.

Association of Official Analytical Chemists - AOAC. (1995). Official methods of analysis (16th ed.). Arlington: AOAC.

Award, J., Dawkins, N. L., Shikany, J., \& Pace, R. D. (2009). Boost for purslane (pp. 58-60). South Africa: Foundation for Professional Development (FPD)-Health and Wellness.

Balestra, F. (2009). Empirical and fundamental mechanical tests in the evaluation of dough and bread rheological properties (Dissertation thesis). Alma Mater Studiorum, Università di Bologna, Bologna.
Costa, G. M., Paula, M. M., Costa, G. N., Esmerino, E. A., Silva, R., Freitas, M. Q., Barão, C. E., Cruz, A. G., \& Pimentel, T. C. (2020). Preferred attribute elicitation methodology compared to conventional descriptive analysis: a study using probiotic yogurt sweetened with xylitol and added with prebiotic components. Journal of Sensory Studies, 35(6), e12602. http://dx.doi.org/10.1111/joss.12602.

De Lorgwril, M., Salen, P., Laporte, F., \& Delriris, J. (2001). Alphalinolenic acid in prevention and treatment of coronary heart diseases. European Heart Journal Supplements, 3(4), D26-D32. http://dx.doi. org/10.1016/S1520-765X(01)90115-4.

El-Demery, M. E. (2011). Evaluation of physico-chemical properties of toast breads fortified with pumpkin (Cucurbita moschata) flour. In Proceedings of the 6th Arab and 3rd International Annual Scientific Conference on: Development of Higher Specific Education Programs in Egypt and the Arab world in the light of knowledge Era Requirements. Egypt: Mansoura University.

Ewerling, M., Steinmacher, N. C., Santos, M. R., Kalschne, D. L., Souza, N. E., Arcanjo, F. M., Souza, A. H. P., \& Rodrigues, A. C. (2020). Defatted chia flour improves gluten-free bread nutritional aspects: a model approach. Food Science and Technology, 40(1, Suppl. 1), 68-75. http://dx.doi.org/10.1590/fst.42118.

Farokhian, F., Jafarpour, M., Goli, M., \& Askari-Khorasgani, O. (2017). Quality preservation of air-dried sliced button mushroom (Agaricus bisporus) by lavender (Lavendula angustifolia Mill.) essential oil. Journal of Food Process Engineering, 40(3), e12432. http://dx.doi. org/10.1111/jfpe.12432.

Fathnejhad-Kazemi, R., Peighambardoust, H., Azadmard-Damirchi, S., Nemati, M., Rafat, A., \& Naghavi, S. (2012). The effect of purslane powder on chemical characteristics, fatty acids profile and sensory quality of bread. Iranian Journal of Nutrition Sciences and Food Technology, 7(3), 11-18.

Fu, L., Tian, J. C., Sun, C. L., \& Li, C. (2008). RVA and farinograph properties study on blends of resistant starch and wheat flour. Agricultural Sciences in China, 7(7), 812-822. http://dx.doi.org/10.1016/ S1671-2927(08)60118-2.

Goyat, J., Passi, S. J., Suri, S., \& Dutta, H. (2018). Development of chia (Salvia hispanica, L.) and quinoa (Chenopodium quinoa, L.) seed flour substituted cookies-physicochemical, nutritional and storage studies. Current Research in Nutrition and Food Science, 6(3), 757769. http://dx.doi.org/10.12944/CRNFSJ.6.3.18.

Guijarro-Fuertes, M., Andrade-cuvi, M. J., Bravo-vasquez, J., Ramosguerrero, L., \& Vernaza, M. G. (2019). Andean blueberry (Vaccinium floribundum) bread: physicochemical properties and bioaccessibility of antioxidants. Food Science and Technology, 39 (1, Suppl. 1), 56-62. http://dx.doi.org/10.1590/fst.30317.

Guimarães, J. D. L. B., Calixto, F. A. A., Keller, L. A. D. M., Silva, L. E., Furtado, A. A. L., \& Mesquita, E. D. M. (2019). Development of a low commercial value fish-sausage from the fish trawling "mix" category. Food Science and Technology, 39(1, Suppl. 1), 115-121. http://dx.doi.org/10.1590/fst.38317.

Hussien, H. A., \& Salem, E. M. (2016). Development of gluten free snacks fortified with purslane (Portulaca oleracea) powder. Journal of Food and Nutrition Sciences, 4(6), 136-144. http://dx.doi.org/10.11648/j. jfns.20160406.11.

Iglesias-Puig, E., \& Haros, C. M. (2013). Evaluation of performance of dough and bread incorporating chia (Salvia hispanica L.). European Food Research and Technology, 237(6), 865-874. http://dx.doi. org/10.1007/s00217-013-2067-x.

Jalalizand, F., \& Goli, M. (2021). Optimization of microencapsulation of selenium with gum Arabian/Persian mixtures by solvent evaporation method using response surface methodology (RSM): soybean oil 
fortification and oxidation indices. Journal of Food Measurement and Characterization, 15(1), 495-507. http://dx.doi.org/10.1007/ s11694-020-00659-y.

Karshenas, M., Goli, M., \& Zamindar, N. (2018). The effect of replacing egg yolk with sesame-peanut defatted meal milk on the physicochemical, colorimetry, and rheological properties of lowcholesterol mayonnaise. Food Science \& Nutrition, 6(4), 824. http:// dx.doi.org/10.1002/fsn3.616. PMid:29983945.

Karshenas, M., Goli, M., \& Zamindar, N. (2019). Substitution of sesame and peanut defatted-meal milk with egg yolk and evaluation of the rheological and microstructural properties of low-cholesterol mayonnaise. Food Science \& Technology International, 25(8), 633641. http://dx.doi.org/10.1177/1082013219853931. PMid:31155956.

Kouassi-Koffi, J. D., Sturza, A., Paucean, A., Man, S., Muresan, A. E., Petrut, G., Muresan, V., \& Muste, S. (2019). Effect of glucose oxidase addition on the textural characteristics of wheat-maize dough and bread. Food Science and Technology, 39(1), 127-133. http://dx.doi. org/10.1590/fst.27117.

Lee, B. D., Lee, S. J., Jeon, M. R., Yun, S. W., \& Kim, M. R. (2015). Quality characteristics and antioxidant activities of morning bread containing Portulaca oleracea L. Korean Journal of Food and Cookery Science, 31(5), 524-533. http://dx.doi.org/10.9724/kfcs.2015.31.5.524.

Maghamian, N., Goli, M., \& Najarian, A. (2021). Ultrasound-assisted preparation of double nano-emulsions loaded with glycyrrhizic acid in the internal aqueous phase and skim milk as the external aqueous phase. Lebensmittel-Wissenschaft + Technologie, 141, 110850. http:// dx.doi.org/10.1016/j.lwt.2021.110850.

Menteş, Ö., Bakkalbaşşi, E., \& Ercan, R. (2008). Effect of the use of ground flaxseed on quality and chemical composition of bread. Food Science \& Technology International, 14(4), 299-306. http:// dx.doi.org/10.1177/1082013208097192.

Mirani, A., \& Goli, M. (2021a). Optimization of cupcake formulation by replacement of wheat flour with different levels of eggplant fiber using response surface methodology. Food Science and Technology (Campinas), In press.

Mirani, A., \& Goli, M. (2021b). Production of the eggplant-fiber incorporated cupcake and evaluating its chemical, textural and colorimetric properties over a ten-day storage time. Journal of Food Processing and Preservation, e15311. http://dx.doi.org/10.1111/jfpp.15311.

Naghavi, S., Mogaddam, M. J., Peighambardoust, S. H., Ghaffari, A. O., \& Azadmard-Damirchi, S. (2011). Fortification of wheat flour with purslane seed powder: Studying flour characteristics and dough rheological properties. Journal of Food Research, 21(3), 281-293.

Nazari, F., \& Goli, M. (2017). The effect of replacing oil with water and $\mathrm{NaCl}$ with $\mathrm{KCl}$ on soybean oil hydrolysis and oxidation in canned skipjack tuna fish at the end of the 18-month shelf life. Food Science and Biotechnology, 26(1), 49-53. http://dx.doi.org/10.1007/s10068017-0007-4. PMid:30263509.

Omara-Alwala, T. R., Mebrahtu, T., Prior, D. E., \& Ezekwe, M. O. (1991). Omega-three fatty acids in purslane (Portulaca oleracea) tissues. Journal of the American Oil Chemists' Society, 68(3), 198-199. http:// dx.doi.org/10.1007/BF02657769.

Parsaei, M., Goli, M., \& Abbasi, H. (2018). Oak flour as a replacement of wheat and corn flour to improve biscuit antioxidant activity. Food Science \& Nutrition, 6(2), 253-258. http://dx.doi.org/10.1002/ fsn3.524. PMid:29564090.

Romankiewicz, D., Hassoon, W. H., Cacak-Pietrzak, G., Sobczyk, M., Wirkowska-Wojdyla, M., Ceglinska, A., \& Dziki, D. (2017). The Effect of Chia Seeds (Salvia hispanica L.) Addition on Quality and Nutritional Value of Wheat Bread. Journal of Food Quality, 2017, 1-7. http://dx.doi.org/10.1155/2017/7352631.

Rubatzky, E. V., \& Yamaguchi, M. (1997). World vegetables: principles, production and nutritive values. New York: Chapman \& Hall. http:// dx.doi.org/10.1007/978-1-4615-6015-9.

Sass, C. A. B., Pimentel, T. C., Aleixo, M. G. B., Dantas, T. M., Oliveira, F. L. C., Freitas, M. Q., Cruz, A. G., \& Esmerino, E. A. (2020). Exploring social media data to understand consumers' perception of eggs: a multilingual study using Twitter. Journal of Sensory Studies, 35(6), e12607. http://dx.doi.org/10.1111/joss.12607.

Sazesh, B., \& Goli, M. (2020). Quinoa as a wheat substitute to improve the textural properties and minimize the carcinogenic acrylamide content of the biscuit. Journal of Food Processing and Preservation, 44(8). http://dx.doi.org/10.1111/jfpp.14563.

Sharoba, A. M., El-Desouky, A. I., Mahmoud, M. H., \& Youssef, K. M. (2009). Quality attributes of some breads made from wheat flour substituted by different levels of whole amaranth meal. The Journal of Agricultural Science, 34(6), 6601-6617.

Stephan, J. M. (1994). Purslane: fact sheet HS-651 (p. 7). Florida: Florida Cooperative Extension Service, Institute of Food and Agriculture Sciences, University of Florida.

Zaghian, N., \& Goli, M. (2020). Optimization of the production conditions of primary (W1/O) and double (W1/O/W2) nanoemulsions containing vitamin B12 in skim milk using ultrasound wave by response surface methodology. Journal of Food Measurement and Characterization, 14(6), 3216-3226. http://dx.doi.org/10.1007/ s11694-020-00567-1.

Zonoubi, R., \& Goli, M. (2021). The effect of complete replacing sodium with potassium, calcium, and magnesium brine on sodium-free ultrafiltration Feta cheese at the end of the 60-day ripening period: physicochemical, proteolysis-lipolysis indices, microbial, colorimetric, and sensory evaluation. Food Science \& Nutrition, 9(2), 866-874. http://dx.doi.org/10.1002/fsn3.2050. 